\title{
Research on Financing Problems of Small and Medium-sized Enterprises in Jilin Province
}

\author{
Huiping Zhang \\ Finance Department \\ Jilin College of Business and Technology \\ Changchun, China
}

\begin{abstract}
Small and medium-sized enterprises (SMEs) in Jilin province play an important role in economic development, but its own development faces financing difficulties. In this paper, by analyzing the present situation and exploring the reason, it proposes that we should be taken to strengthen the financial policy support, to establish a multi-level financing channel of SMEs, to strengthen the construction of SMEs information and simplify examination and approval procedures, to improve the efficiency of credit financial countermeasures to solve them.
\end{abstract}

Keywords—Jilin province; SMEs; financing problems

\section{INTRODUCTION}

SMEs are playing an increasingly important role in Jilin province's economic development. By the end of 2011, there were 129,000 small and private enterprises in Jilin province, a total of 129000 units, $98.5 \%$ of the total number of enterprises, and provides $72 \%$ of jobs in cities and towns, the added value of its complete $50.5 \%$ of the province's GDP [1], visible, its contribution rate has exceeded half, powerful booster is the economic development of Jilin province. Research showed that many researchers at home and abroad, the problem of financing is decided to SMEs survival and the development of a key factor, therefore, the thorough analysis and research of Jilin province SMEs financing difficulties faced by, can explore to effectively solve the financial countermeasures, is in the current economic development of Jilin province is an urgent need to solve an important problem.

\section{FINANCING DifFICULTIES OF SMES IN JILIN PROVINCE}

\section{A. Financing Gap Is Huge}

According to the sampling survey of industry and information technology department in Jilin province, and measure the effective money demand in 2012 in Jilin province SMEs in 110 billion yuan, including 35 billion yuan in medium-sized enterprises, small businesses, 44 billion yuan, the miniature enterprise 32 billion yuan; SMEs can raise around 70 billion yuan through various possible channels, and the capital gap of the whole year is around 40 billion yuan [1].This ratio means that the province's SMEs, on average, will be nearly $36 \%$ of the funds are not being met, and small micro enterprise financing gap is bigger, it will generally influence of SMEs of the new project put into production, new product development and technical upgrading ability, thus seriously affect its development and expansion.

\section{B. Financing Method Is Single}

At present, the Jilin province SMEs through a bank loan financing, equity financing, industry chain, collection notes, in the form of mutual insurance pool financing and financing, financing way although the diversified development trend, but due to the imbalance of each financing way development in Jilin province, lead to the difference in the position in SMEs actual financing activities is different. Data is calculated, according to the 2012 financing bank loans accounted for the proportion of SMEs financing in the province is as high as $86 \%$, belong to outshine others, it shows that in fact in Jilin province SMEs financing way also is single.

\section{High Cost of Financing}

When SMEs in Jilin province raise money from commercial Banks, they usually have no preferential interest rate, and the average interest rate is around $12 \%$. If SMEs raise capital from small loan companies and pawnshops, the cost will be more than $20 \%$.The most expensive is private borrowing, with interest rates mostly at $2(20 \%)$ and $3(30 \%)$ [1]. Compared with the same period, the loan interest rate of SMEs is significantly higher than that of the large enterprises from commercial bank lending rate, which is basically at the level of $6.15 \%$. At the same time, the SMEs of direct financing costs are high and collection of bonds, for example, issue though interest rates remain at the levels of benchmark interest rate, but in the process of issuance to the guarantee agencies, law firms, accounting, securities and other intermediaries pay commission, compared with large enterprises, financing costs are high.

\section{The Financing Time Is Longer}

When taking a bank loan financing of SMEs, due to the bank for the issuance of a short-term loan usually go through credit assessment, enterprise financial analysis, put forward investigation report and a lot of link such as loan review committee, so the financing process required for a long time, if is a loan, the review to be more strict, usually need 1 to 2 months' time [2]. If the financing of issuing collection bonds is adopted, the number of enterprises involved shall be approved by the competent authorities and reported to the central bank 
and the securities regulatory commission for filing, and the issuance of approval shall be long [3]. This kind of longer financing process cannot effectively solve the "urgent" characteristics of capital demand in the development of SMEs, and it will often mislead time and affect the use efficiency of funds.

\section{REASONS FOR THE FORMATION}

\section{A. Financial Policy Support Is Inadequate}

In the process of development of SMEs, rely on internal financing to solve the amount of capital is limited, most of the funds are to be provided by exogenous financing, low level of industry and SMEs, weak foundation and characteristics of small size and weak anti-risk ability, and lead to the competition on the exogenous financing but big enterprise, therefore, if does not carry on the policy finance tilt, cannot effectively solve the problem of its insufficient funds. Although our country issued "SMEs Promotion Law", but its role for SMEs financing is limited, at present, the national macro financial policy support for Jilin province SMEs development is not enough. At the same time, there is a lack of policy-based financial institutions dedicated to financing SMEs, which is also the cause of the financing gap.

\section{B. Financing Channels Are not Smooth}

Jilin province at present to realize equity financing through the capital market is few, the number of SMEs listed on the new three board of the country's current enterprise has reached 621 , and Jilin province in the new three board market listed companies only a "travel the world", in the second board market listed companies only seven [4].At the same time, due to the Jilin Changchun regional SMEs property rights trading market of Jilin province, property right transaction center began to set up in 2005, forming time is not long, including a collection of notes in the province of direct financing way also in its infancy, leading to the limited number of SMEs financing channels through the above, most of the money must be addressed through a loan from the bank. And in bank loans, mainly in agricultural bank, construction bank, bank of Jilin's loan is given priority to, SMEs competition but the advantage of the Banks clients, large enterprises, can receive money is limited. Visible, small and medium enterprise financing channel is narrow, and not smooth.

\section{Information Asymmetry}

Compared with loans to large enterprises, loans to small and medium enterprises are confronted with more serious information asymmetry problems. Regularly publish financial statements with large enterprises, SMEs generally adopt family management mode, financial system is not sound, the information is not public, unable or unwilling to publish financial conditions, existence of lack of good faith, the information asymmetry situation will surely increase the risk of bank loans to small and medium enterprises. Therefore, in the process of bank loans to SMEs need to pay a much higher than large enterprise audit fees, this part of the spending is bound to add to the loan interest rate, increase the cost of financing of SMEs. And to reduce loan risks, Banks usually require SMEs to provide collateral, which in turn lead to some related fees (such as valuation fee, Cost of verification, etc.), to further improve the financing cost.

\section{Loan Approval Formalities Are Cumbersome}

Commercial Banks in the process of loan approval, usually the approval of loans to SMEs should be stricter than the approval of large enterprises. Generally speaking, commercial Banks usually include negotiation, information, bank investigation, review, loan, contract mortgage and loan origination. Large due to the risk of lending to small and medium enterprises, commercial Banks in lending to small and medium enterprises, usually more strictly to the execution of each link, especially pay attention to a review of the situation of the mortgaged property, in the absence of the mortgaged property, will require companies to provide accounts receivable pledge loan. In failing to provide mortgage (pledge), Banks will usually require companies through daily clearing bank, to understand the cash receipts and cash payments for the enterprise, enterprise's credit rating and approval and the high credit rating of SMEs to make loans.

\section{E. The Credit Guarantee System Needs to Be Improved}

The credit guarantee system of SMEs in Jilin province needs to be improved, and it can't adapt to the guarantee demand of many SMEs in the province. First of all, the small scale of capital guarantee agencies, each guarantee agencies, the average capital is less than 100 million yuan, the county capital guarantee agencies smaller, restricting its guarantee ability, make it difficult to get financial institutions, guarantee function is limited. Second, there is no reasonable risk-sharing mechanism between the guarantee agencies and Banks. In order to diversify and avoid risk, the guarantee institution needs to take a risk share with the bank based on the size and duration of the loan. But the fact is in the Jilin province, except a handful of policy guarantee agencies, guarantee business shall be borne by the guarantee agencies solely, increases the risk of the guarantee agencies, limiting its business.

\section{THE FINANCIAL COUNTERMEASURES}

\section{A. Strengthen Financial Policy Support}

First, our country has issued such as should be informed about support for SMEs loan etc. the execution of laws and regulations in place, and according to the actual situation in our country, with reference to the practice of developed countries such as America, Japan, in legislative support for SMEs financing. Secondly, it can learn from the experience of Japan and other countries to establish policy-based financial institutions specialized for the service of SMEs, and effectively expand the source of funds for SMEs. Again, Jilin branch should be based on the actual situation of the province, determine the local commercial bank loans to SMEs should issue the proportion, can through the regular check, for the business good commercial Banks give appropriate reward, also can guide the internal incentive mechanism, give awards to relevant personnel, improve the enthusiasm of the staff engaged in SMEs service, to ensure the funds needed for the local development of SMEs. 


\section{B. Establish a Multi-level Financing Channel for SMEs}

First, it is important to promote the financing of SMEs in Jilin province to the second and third board markets. Secondboard market for small and medium-sized high-tech enterprises or fast-growing enterprises solve the problem of money, the new three board market need to meet the remaining two years, have the ability to continue as a going concern and improve the corporate governance mechanism, equity clarity can be sent to market conditions, due to the lower threshold, broader, more suitable for SMEs financing, therefore, should actively encourage SMEs to strengthen their own economic strength, the respect such as capital and scale of construction, in order to achieve the requirements of the securities market, to realize equity financing. Second, should give full play to the Jilin Changchun property right transaction center, the role of the regional market, to get a multitude of SMEs in the province to use the platform to develop and promote new financing way solving the problem of money. And can also draw lessons from the small and medium-sized commercial Banks and the German savings Banks, youth association of business operators and other civil financial institutions in the development of SMEs successful experience, an injection of new funds in a step-by-step and systematically to promote the construction of small and medium-sized private financial institutions.

\section{Improve the Construction of Information Banks for SMEs}

In the people's bank of China Changchun center branch established "SMEs financing information database management system", on the basis of branch of Jilin province, Jilin provincial banking supervision authority and the people's bank of Changchun central branch should communicate and cooperate with departments such as the ministry of industry and information technology, to use a variety of effective channels for SMEs all aspects of information collection, to further improve the construction of information in various data resources, to provide effective information for all financial institutions query service. The commercial bank takes the data data provided by the information bank for the approval of the loan, which can save some of the cost of review and effectively reduce the cost of review. At the same time, according to the data provided by the database data, can also according to set up a certain amount of SMEs with good credit records of credit, excellent credit condition for enterprises to provide more financing opportunities.

\section{Simplify the Approval Process and Improve the Efficiency of the Loan}

We should improve the loan business of SMEs in accordance with the characteristics of "short, frequency and urgent". First of all, the focus on small business growth, enterprise management ability and enterprise's credit status of credit rating evaluation measures in such aspects, as standard as the important basis of loan approval. Secondly, to simplify examination and approval procedures, insisted on performing loan procedure, guard against credit risk at the same time, should be appropriate to simplify examination and approval of processing procedures, such as internal audit can reduce bank number, avoid repeat the phenomenon such as examination and approval, in order to improve the efficiency of financial services. Meanwhile, we actively carry out research and development, and continuously introduce financing products that meet the characteristics of the capital requirements of SMEs to effectively solve the financing problems of SMEs and promote their healthy development.

\section{E. Construction of Credit Guarantee System}

First of all, the government of Jilin province should strengthen the support of the credit guarantee agencies, effectively improve the fund scale of guarantee institutions, and make its guarantee function effective. Governments at all levels, especially municipal governments, should inject capital into policy-based guarantee institutions at the same level and increase their funding sources. Secondly, the reasonable risk sharing mechanism between guarantee institutions and Banks should be established actively. Can be reference to the international current by financial institutions to assume the risk of $20 \%$ to $30 \%$, from $70 \%-70 \%$ of the risk of guarantee agencies, actively guide and encourage the Banks and guarantee agencies to be negotiated share proportion, realize the share of credit risk. At the same time, we should give full play to the role of northeast China SMEs credit reinsurance co., LTD., and strive to build a new guarantee system for Jilin province with its core and guarantee institutions at all levels.

\section{CONCLUSION}

To sum up, solve the problem of Jilin province SMEs financing, need effective countermeasures of financial support, from the macro financial policy, capital market construction, credit information database construction, the loan approval process and credit guarantee system construction and other aspects to obtain, from different angles to strengthen construction, increase the capital investment of SMEs, promote the healthy development of SMEs.

\section{REFERENCES}

[1] Bai xugui, deputy director of the department of economic and social development of retired cadres in the province, report on the general report on the economic and social development of retired cadres and the key training courses of theoretical backbone of the 26th issue[EB/OL]. http://gxt.jl.gov.cn/myjjte/myjj_tfdt/201208/t20120807_1253723.html,2 012-06-20.

[2] Sun shaoyan, Sun bo. Financing problems and countermeasures of SMEs in jilin province - and the theory of "fuzon mode" [J]. Journal of liaoning university (philosophical social science edition), 2012, (3): 8489.

[3] Li yan zheng. The ministry of industry and information technology is urgent to investigate the collection and approval of SMEs [EB/OL] http://www.ce.cn/macro/more/201003/17/t20100317_21132058.shtml,2 010-03-17.

[4] Zhao shuang. There are 621 new third board enterprises listed in China, only 1 in jilin province [EB/OL]. http:// www.jl.xinhuanet.com/2012jlpd/2014-02/22/c_119453562.htm, 201402-22. 